Cahiers d'études africaines

197|2010

Jeux de mémoire

\title{
The Formulaic Revolution
}

Song and the "Popular Memory" of the Mozambican Liberation Struggle La révolution en clichés. Chansons et mémoire populaires de la lutte de libération nationale mozambicaine

\section{Paolo Israel}

\section{OpenEdition}

\section{Journals}

\section{Electronic version}

URL: http://journals.openedition.org/etudesafricaines/15828

DOI: 10.4000/etudesafricaines. 15828

ISSN: $1777-5353$

\section{Publisher}

Éditions de l'EHESS

\section{Printed version}

Date of publication: 30 March 2010

Number of pages: $181-216$

ISBN: 978-2-7132-2251-1

ISSN: 0008-0055

\section{Electronic reference}

Paolo Israel, «The Formulaic Revolution », Cahiers d'études africaines [Online], 197 | 2010, Online since 10 May 2012, connection on 20 April 2019. URL : http://journals.openedition.org/ etudesafricaines/15828; DOI : 10.4000/etudesafricaines.15828

This text was automatically generated on 20 April 2019.

(c) Cahiers d'Études africaines 


\title{
The Formulaic Revolution
}

\author{
Song and the "Popular Memory" of the Mozambican Liberation Struggle \\ La révolution en clichés. Chansons et mémoire populaires de la lutte de \\ libération nationale mozambicaine
}

\section{Paolo Israel}

1 The history of the Mozambican Struggle of National Liberation (Luta de Libertação Nacional), which the Front for the Liberation of Mozambique (Frelimo) fought for ten years against Portuguese colonialism (1964-1974), has been increasingly memorialised and monumentalised, as the ideological breeding ground of the postcolonial Nation. Nationalism deployed there its usual means to reproduce and occupy memory: public holidays, iconography, museums, mausoleums, remembrances of heroes, music, dance, political meetings, and so forth ${ }^{1}$.

2 Memorialisation affects living memory as well. Nationalist narratives of the Luta infuse the personal biographies of those who made the Luta and that the Luta remade, to the point where the distinction between "things as they were" and "things as we were told they were" becomes subjectively blurred. Lessons learned about the fearsomeness of the insurgents' apparatus of ideological repression; faith in historical representation produced by Frelimo Party; hope in historical regeneration as the promise of that very faith; a sense of faltering of all subjective representations-that things in war are never what they seem, and that vision and power are strict correlates; the consciousness that unity of voice in times of crisis is to be valued more than discordant detail; the rehearsal and codification of war-testimony-displayed during State ceremonies, solicited by researchers and journalists, and required for the attribution of war pensions-as the genre where things are to be told as they are supposed to have unfolded: here one might find reasons for the intertwining between monumental narratives and personal biographies. The naïve interviewer's question: "How was life during the Struggle?" triggers testimonies woven with recurrent tropes, sparse intimate details, and looming fear.

3 In the last decades, strands of Africanist scholarship have excavated genres of African popular orality in the search for unofficial, poetic visions of history; and alternative sites 
of memory. Not only popular oral genres, such as songs and praise poetry, are thought to convey "maps of experience" (Vail \& White 1991: 147), "styles of historiography" (Coplan 1993: 80, 1994) or "historiologies" (Fabian 1996: 269, fol.), they are sometimes considered as inherently opposing dominant power, as constitutionally counterhegemonic. By and large taking inspiration in Mikhail Bakhtin's work on carnival (Bakhtin 1965), Jack Mapanje, Leroy Vail and Landeg White define the essence of African orature in terms of "poetic license": "The convention that poetic expression is privileged expression, the performer being free to express opinions that would otherwise be in breach of other social conventions" (Vail \& White 1991: 319). Similarly, Karin Barber $(1987,1997)$ understood African popular culture as marked by unofficiality and Johannes Fabian (1998) as providing fleeting "moments of freedom" for the oppressed.

Researching the oral traditions of the people that live in the areas where the Mozambican Liberation Struggle was mainly fought, and where Frelimo's revolutionary project was piloted-the mythic "liberated zones" first freed from colonial rule in the northerly province of Cabo Delgado ${ }^{2}$-one finds a somewhat different picture. Today as in the last forty years, Makonde dances of all kinds and for all occasions-from masquerade to initiation, from funeral to divertissement-showcase songs that revolve around Frelimo's political project and its founding narrative, the Liberation Struggle. These songs are often referred to as "revolutionary songs" ("dimu dya mapindushi"), or "political songs" ("dimu dya shiashya"), as opposed to older genres and to more mundane, playful or amorous lyrics. Related to social practices such as State rituals and dance competitions, to a wide reconfiguration of collective identity, and to a dialectics of generations, contemporary Makonde revolutionary singing is a form of active memory of the Struggle -of "imparting history" ("kwimyangidya") or "intensive reminding" ("kukumbuanga").

However, one would look there in vain for "lived memories" of the Struggle, for alternatives historiologies or maps of that extraordinary experience of which the Makonde were protagonists. One finds instead a recitation of trite tropes, reproducing the silhouette of the Struggle as in the official history-myth.

Memory does not simply correspond to that which is remembered. The languages, genres, images and words through which one remembers, constitute memory as much as the content or subject-matter itself. This article engages a historical reconstruction of the formation of Makonde "revolutionary singing" as genre of memorialisation, which coalesced in the course of the Liberation Struggle3; tracking the "descent" of elite formulas and watchwords into popular orality. Along this trajectory, we will encounter wartime genres that were later forgotten or foregone, which refer to moments when the "space of experience" and the "horizon of expectation" (Koselleck 1990) of the Struggle were still filled with uncertainty and the sense of possibility. Progressively, these singing expressions were reorganised around socialism's nodes of meaning. Ideological tropes, elaborated by Frelimo's "courtly" composers, were appropriated in popular singing. The relations between the "people" and their leaders were made apparent by the "enactment of power" in the organization of the performance space (Thiong'o 1997).

My main contention is that, unofficiality, heteroglossia, metaphor, and poetic license that appear in genres that have been marked out as "popular" in academic discourse, are by no means intrinsically "popular". On the contrary, they might well be the first victims of populist modes of political actions, that is, of a politics grounded on a concept of "people" ${ }^{4}$. 


\section{Frelimo's Populism}

5 Frelimo's Utopia was condensed in the formula of the New Man (o homem novo) ${ }^{5}$. Five hundred years of slavery and colonialism adulterated all that was good about "traditional" African society-so the story went-bringing about an insoluble complicity between "obscurantism" and "oppression": hence the necessity of making a "clean slate" of all social institutions, working to the creation of new persons and mentalities ${ }^{6}$.

6 The ideology of the New Man was Frelimo's declination of a politics of populism 7 . Ernesto Laclau (2005) argues that "the construction of the people" is the quintessential political act; and that consequently the question of populism is at the core of politics. A politics of populism arises when a multiplicity of singular demands are articulated in an "equivalential chain" through an act of naming. The name that establishes a collective political identity-Laclau draws here to the Lacanian concept of the "nodal point" or "quilting point" ("point de capiton")-is an empty signifier. "People", "workers", etc. are not understandable as having a substantial meaning, but simply as the signifiers that hold together a political identity. The act of "quilting" a political identity around "the people" creates an irremediable fracture in society. As soon as the People is named, an Enemy arises. The creation of a political identity-quilted around the naming of a People and the emergence of a fracture defining an Enemy-is eminently libidinal: the process is invested with massive psychic energies (Laclau 2005: X). The function of charismatic leadership in populism is related to this libidinal investment: the Leader is the incarnation of the empty signifier: "[...] the symbolic unification of the group around an individuality [...] is inherent to the formation of a "people"' (ibid.: 100).

7 The endeavour of "extracting the People from the people" (Žižek 2008: 261-263)-of dividing the People from the Enemy-needs an elite who guarantees for the transformation, produces the discourse defining what belongs to the People and what does not, and wields the means to repress or annihilate what falls in the latter group. "By conceiving of himself as an agency through which the People gives birth to itself, the Leader assumes the role of a deputy from (of) the future; he acts as a medium through which the future, not yet existing People organises its own conception" (ibid.: 262). "Popular culture" is the result of this operation: the violent positioning of a set of cultural idioms into a hierarchised space of elite vs. people, where the former draw their legitimacy on possessing the key to what the latter is (the elites are elites because they know what the People is/will be, and because they can shape it into form, like a tree, by cutting useless branches).

8 And indeed, in Frelimo ideology two symbolic figures oversee the paradoxical process of creating new men out of old ones. The Leader, who has already undergone the transformation, attests to its possibility. The Enemy, who embodies all that is to be erased, serves as a reminder of the need for struggle, a justification for failure, and a scapegoat (Lefort 1986: 292-306). Both the Leader and the Enemy are defined in relation to their capacity to act. The Leader is an allegory of perfect agency, of transparent selfmastery. The Enemy's agency is lacking (the lazy) or ill-addressed (the weaver of subterfuge).

Launched as a slogan at the onset of Independence (1975) (Vieira 1978; Zawangoni 2007), the New Man was given mythical consistency through historical reference to the Armed Struggle of National Liberation (Luta Armada de Libertação Nacional) fought against 
Portuguese colonialism (1964-1974). The Struggle provided an array of significant tropes for the work of the social imagination. The Leader embodied the qualities of the heroes who fought colonialism; the Enemy those of the cowards and traitors detected and summarily dispatched by the vigilant guerrillas. Forged by the mayhem and discipline of war and by a new mode of life based on collective production, militarised settlement and modernist education, the "vanguards of the Revolution"-soldiers, "People" and pupils of the liberated zones-would stand as an example for the Nation to come. If the discourse of the New Man has long been abandoned in Mozambique, the history-myth of the Struggle has continued to live a life of its own, reproduced in a variety of expressive forms across the social spectrum: literature, photography, architecture, dance, theatre, visual arts-and song.

\section{Hush down Your Drums}

9 In the apogee of colonial rule (1938-1962), song and dance traditions in Northern Mozambique were complex and diverse. Drums-a "drum" (ing'oma, ikoma, ngoma, etc.) being the widespread synecdoche for a song-cum-dance ${ }^{8}$ genre-featured at the core of all aspects of social life, from the ritual, to the mundane to the political. Far from being spontaneously collective, most "drums" functioned as groups, often under the patronage of an individual -wealthy, powerful or passionate. Drum groups chose their members, rehearsed, invented new songs and choreographies and engaged in extensive artistic competitions 9 . The relationship of singular genres with occasions, generations, and gender were fairly liquid. Connected by centuries of exchanges and transformations and shaped by influences as vast as the Indian Ocean world, "drumming" traditions fell into ethno-linguistic partitions, quite porous but stylistically connoted in a system of mutual recognition.

The colonial State and its functionaries were not indifferent to the call of the drum, to its exotic and primitive appeal. "Imperial spectacles" (Apter 2002) inevitably featured a region's most famous "drums", dragged volens nolens to dance for the reign's glory. National and religious holidays as well as the visit of leaders and personalities became regular occasions for the performance of drums, the more so the closer the White man's institutions of power.

11 Songs' poetic idioms played on a wide gamut of registers: codified ritual refrains, proverbial wisdom, elliptic and evocative couplets, self-celebratory exclamations and elaborated individual verse. All these could be summoned to articulate critical visions of history and society. The colonial master could barely listen to these voices. When it managed to, and found the content displeasing, the consequences could be dire.

Nationalist unrest came to the northerly district of Cabo Delgado as the flood fills the lowland. In 1963, the leadership of the newly found Front for the Liberation of Mozambique (Frelimo) in Dar-Es-Salaam judged that the Mueda plateau was to be the battlefield of a war waged against the Portuguese. Not only was it in the finest strategic position to support a guerrilla war backed from Tanzania, close as it was to the border, and covered in dense bush thickets. Mueda's people had also shown a remarkable degree of "nationalist consciousness" firstly in the dramatic episode of the 1960 revolt, then in transiting en masse from an "ethnic-based" organisation to Frelimo (Adam 1993; Cahen 1999; West 2005). The Portuguese were equally worried about insurgency in the area, which they kept under close scrutiny. The first shot of the Liberation struggle (1964) 
found most of the Makonde already dispersed in the bush, as the proverbial water in which the fish would thrive.

Drums are heard far and wide, and detectability through sound was one luxury that the people supporting the war effort could not afford. In the branches and localities under Frelimo's control-precarious huts in remote lowlands, with the constant threat of incursions, and the creeping suspicion of treachery-all "drums" had to shut up and be vigilant, waiting for better times to raise their voices.

But expectations of something different than complete precariousness were to be deluded soon; as it turned out that-despite all reassurances-the war was there to last:

\begin{tabular}{|l|l|}
\hline Chaime Nimande kwa-Ntumbati & The chairman Nimande from Ntumbati \\
\hline Sema nkutano rojino & He calls an assembly at the locality \\
\hline Mwezi uja wa-uhuru & “The coming month we will have inde pendence! \\
\hline Kumbe wazee wa-uwongo & " It turns out elders can lie ${ }^{10}$. \\
\hline
\end{tabular}

AMÉRICO NAMPINDO PLAYS NGODA (RUI ASSUBUJI)

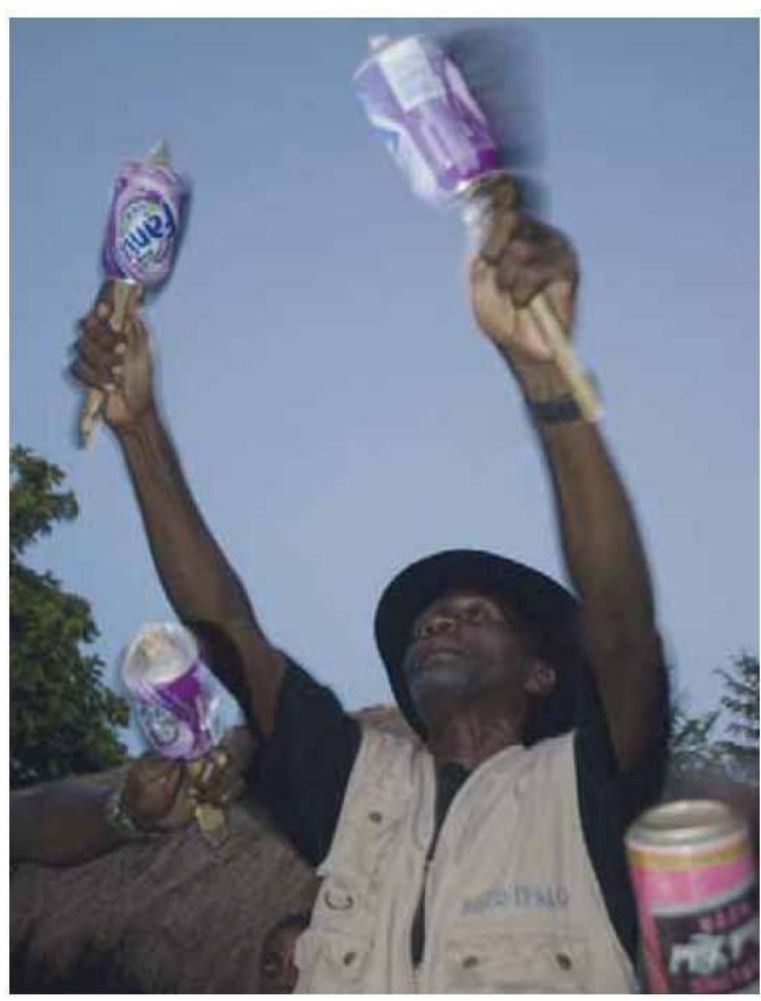

\section{New Maize in Old Rattles}

\begin{tabular}{|l|l|}
\hline Ngwimbanga muda & I sing the times \\
\hline Moda ya maduvano & The mode of nowadays \\
\hline
\end{tabular}




\begin{tabular}{|l|l|}
\hline Ye ye ye & Ye ye ye \\
\hline Ngoda aunavini' vila & Don't dance ngoda just like this \\
\hline Bila shaleko & Without a sentinel \\
\hline Nsheme nkutano & We call a meeting \\
\hline Mumpigi' Lingambwanda & We test Lingambwanda \\
\hline Lingambwanda wena, kapalaleshe & Lingambwanda, go and spy \\
\hline Ukaigwa vajunganga & If you hear noises \\
\hline Nawika dao & Don't come like this \\
\hline Ing'ondo & [This is] war ${ }^{11} \cdot$ \\
\hline
\end{tabular}

Sung to the rhythm of rattles made with used cans and filled with dried maize (ngoda, the commonest food of foot soldiers), and taking its name therefrom, ngoda was the first new "drum" of the war years, invented- so it is said-by the soldier Lingondo. A circular dance, it drew on the ancient and widespread drum nkala, also incorporating songs from various genres. The singing style resembled the so-called "nge-nge-nge" funerary singing, in which two people intone descending pentatonic scales in a sort of "fugue", punctuated by euphonic syllables (nge, ndiyo).

Celebrating the "times" (muda, Kiswahili) or the "mode" (moda, Portuguese)-the two words being made undistinguishable-of "nowadays" ("maduvano"), ngoda songs fiddled with old and obscure tunes. Just one new word makes the difference:

\begin{tabular}{|l|l|}
\hline Nge nge nge & Nge nge nge \\
\hline Shina-Nkulaba & The manner of Kulaba's sons \\
\hline Nandenga vatwale vadyoko & Nandenga, carries away the children \\
\hline Vaende kupemba & He takes them to Pemba \\
\hline $\begin{array}{l}\text { Vakako' madengo aishama } \\
\text { nalimanyia }\end{array}$ & $\begin{array}{l}\text { He makes them work for the Party He knows better } \\
12 .\end{array}$ \\
\hline
\end{tabular}

Nandenga, the tall terrifying spirit who carries away those disoriented in the bush-a kind of Makonde bogeyman, that is-was first used as a metaphor for colonial forced cotton production. "He makes them work the cotton (vakako' madengo ampamba)" was the first version of the song. When cotton becomes "the Party", is the slippage simply incongruous or inoffensive?

16 Just like Nandenga, the new characters of the transformed war landscape are fantastic apparitions on a blue sky-the Portuguese Major passes above, the guerrilla crawls below: 


\begin{tabular}{|l|l|}
\hline Pita muwa & He passes above \\
\hline Manjolo & The major \\
\hline Andyuka navalola vadyoko vake & He goes and sees his boys \\
\hline Avante avante & Avante! Avante! [Forward, Pt.] \\
\hline Tuvanu mwanda & We people go! \\
\hline Mwaa lilove lyautangwele alivé mana & Because the words that you spoke made no sense ${ }^{13}$. \\
\hline
\end{tabular}

17 Amongst the small formulas (nge, njomba, mama) that embroil the main text, a new word slips in: the "empty signifier" of political action: tuvenentete, we-the-People.

\section{Anthems of Liberation}

In the meantime, another new "drum" had appeared in Mueda: likulutu, military training. Youth began to "dance the training" ("kuvina likulutu") inside the country: with wooden weapons, and in obedience to the cacophony of commands of trainers of various nationalities, each teaching the basic military instructors in their respective languages (Kiswahili, English, Chinese, Arab...). Some of the guerrillas would be selected for training abroad, all transiting through Frelimo's camps in southern Tanganyika.

In these military spaces, musicians educated in choral singing in missions (especially the protestant missions) put their skills to the service of the cause, composing an array of new songs for the Struggle: party anthems, marching tunes, inspirational melodies. Different to other Struggle-song traditions (like the Chimurenga from Zimbabwe), local imagery and musical traditions made their way only marginally in the architecture of Frelimo anthems: in a turn of a phrase, in a peculiar rhythmic syncope, in certain melodic passages, in the structure of call and response ${ }^{14}$. Pentatonic harmonic-melodic patterns and polyrhythm were dislodged in favour of tonal four-part harmonies and regular rhythms. The overall influence of mission imagery was considerable.

Nationalist ideology seeped through, in direct or subtle ways. Jorge Zaaqueu Nhassemu, one of the four major literate composers of Frelimo anthems ${ }^{15}$, educated in Inhambane's missions, remembers composing his first political song, Frelimo avante na Guerra (Frelimo, on with the War) "sitting under a shadow" at Kaporo, the border between Malawi and Tanzania, while waiting for his documents. Arriving in Dar-Es-Salaam, the lyrics of the song had to be slightly changed to fit into the ideological requirements of the movement. The war was not against the Portuguese, he was told, but against Salazar, and he should modify his lyrics accordingly. "After that first time", Zaaqueu commented to me, "I learned the lesson, and I didn't have to change any other song".

Overall, the composition of anthems was part and parcel of the movement of literary effervescence that took place between Dar-Es-Salaam and the war front, resulting in the publication of various gazettes and newspapers, such as 25 de Setembro, Os Heroicos, etc. Maria-Benedita Basto (2006: 176-185), in her pioneering study on the literary formation of the Mozambican Nation, argues that a "vocabulary of ready-made ideas" shaped the 
consistency of the guerrillas' voices. The proliferation of watchwords (nationalist, revolutionary) works to the utopian indistinction of things and names, with a certain suffocating effect: "To the progressive construction of this dictionary corresponds a decrease in the publication of life stories (reports of combat, of fleeing, testimony of colonial experiences), of stories and poems. Actually, the majority of the poems were written during the first years of the Struggle" (ibid.: 185, my translation).

Party and military anthems, produced in a peculiar journey from the church to the camp, squarely occupy today's memorial sound-scape of Liberation. Canções da Luta Armada de Libertação Nacional (Songs from the War of National Liberation) is the recurring title of compilations of songs-triumphal then, nostalgic now-as well as defining the shape of an ideological program of aural memory. From Frelimo Aina Mwisho (Frelimo is infinite) to Nelo Ni Liduva (Today is the day, mourning Josina Machel's death) from Salazar Vai Embora (Salazar go away!), to Exaltemos Mondlane (Let's exalt Mondlane): deeply inscribed in the militant's heart and soul, these melodies can be imagined as the soundtrack to the Museum of the Revolution in Maputo, accompanying, say, black-and-white clichés of Samora Machel crossing the Rovuma River in company of the Chinese, of a youthful Mondlane watching the turbid sun as it sets over Mozambique's Liberated Zones.

\begin{tabular}{|c|c|}
\hline Moçambique, nossa terra bendita & Mozambique, our blessed land \\
\hline Hoje luta pela liberdade & Today fights for freedom \\
\hline Nos queremos a nossa liberdade & We want our freedom \\
\hline Unidade a todo o pais. & Unity in the whole country \\
\hline E o sangue do povo triunfante & And the blood of the triumphing People \\
\hline Vencera o regime Salazar. & Will win Salazar's regime \\
\hline A Frelimo sairá vitoriosa & Frelimo will be victorious \\
\hline Nesta luta pela liberdade & In this struggle for freedom \\
\hline $\begin{array}{l}\text { A sagrada bandeira da Frelimo Flutuara nas nossas } \\
\text { fortalezas }\end{array}$ & $\begin{array}{l}\text { Frelimo's sacred flag Will wave in our } \\
\text { fortresses }^{16} \text {. }\end{array}$ \\
\hline \multicolumn{2}{|l|}{ Old wood for new zithers } \\
\hline Raimundu baba wetu tunkukujugwa & Raimundo father we ask you \\
\hline Utupe lusa wetu tuje' likumbi & Give us the order to launch puberty rites \\
\hline Vanung'unu vetu wetu kukangapalanga & Our little brothers are getting old \\
\hline Utupe lusa wetu tuje' likumbi & Give us the order to launch puberty rites ${ }^{17}$ \\
\hline
\end{tabular}




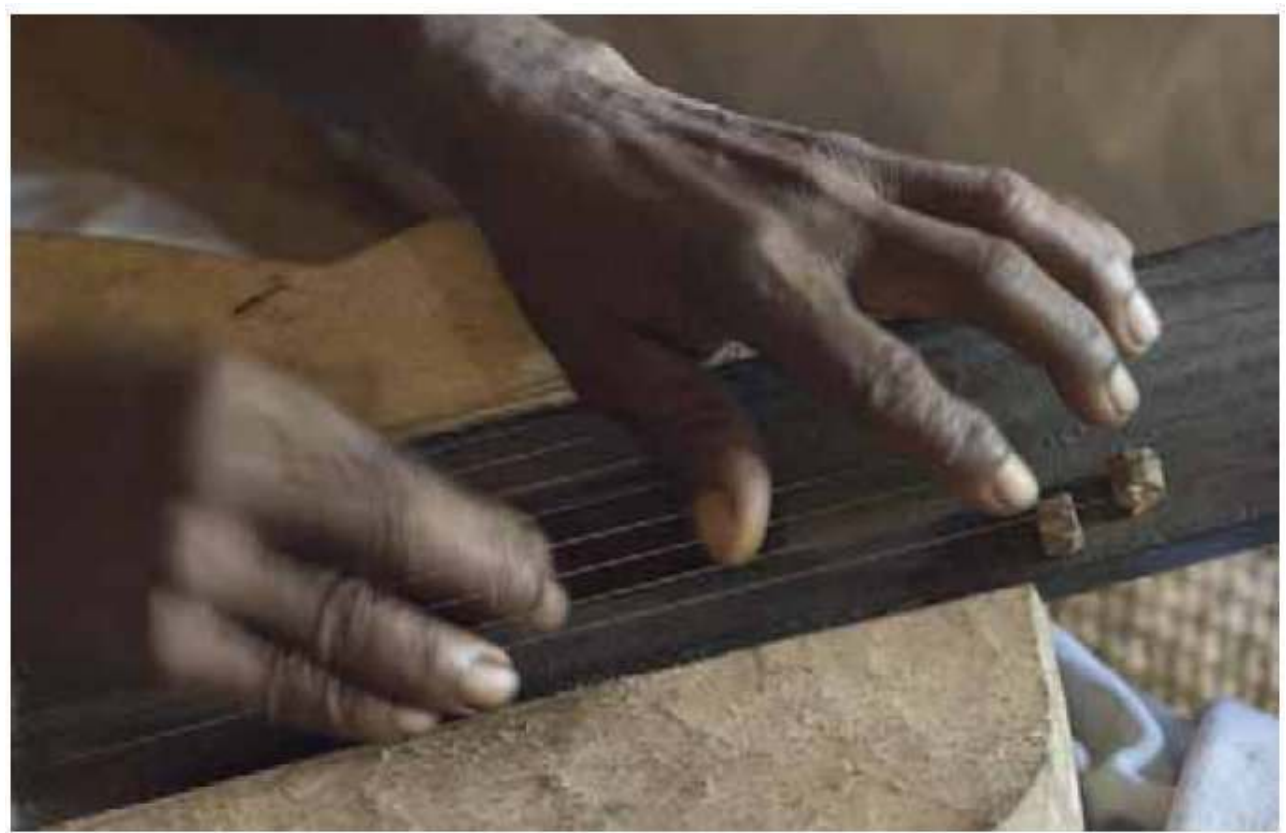

After a moment of consideration, both political and of practical opportunity, it was clear that puberty rituals were to be celebrated even in the precarious war conditions. No noisy masked dancing could mark the entrance and coming out of rituals. But carving skills were put to other good uses. Adding to the traditional board-zithers $i b a n g u^{18} \mathrm{a}$ big resonance chamber, sculpted in the same wood that mapiko masks are made of, and one or two strings, they could be made to resemble "real" guitars. A new fingering technique was devised in order to play on these instruments (now also called magita or magalantoni) the fancy rhythms from the northern coast, especially rumba, twist, and cha-cha-cha.

Magalantoni became extremely popular in the first years of war (1964-1967), a "must" of initiations, funeral ceremonies and all the partying permitted by the situation. Twists (matwisti) brought to athletic extremes were in the highest fashion: "They would bend their heads backward to touch the floor [...] some broke their backs and died right there!" recounted magita master Samuel Mandia with a laugh ${ }^{19}$.

Despite the presence of the enemy, travelling and exchanges were as intense as ever: underground commerce, smuggling of weapons across the border, going back and forth to Tanzania for trainings. Displacements were not a prerogative of soldiers. When travelling, "people" had to notify the nearest Frelimo branch that could assign them to any non-strictly military task such as the transport of war material, or delivering a message. The magalantoni would be carried along. The fashion spread following the footsteps, creating new communities of song and new horizons of artistic fame.

The famous Lingondo, creator of ngoda, is irreverently depicted in a matwisti as he seizes the occasion of a military displacement to exhibit his dancing prowess:

\begin{tabular}{|l|l|}
\hline Lingondo kumbambwe & Lingondo at Mwambe [Macomia] \\
\hline Vandimpukuza & They kicked him out \\
\hline
\end{tabular}




\begin{tabular}{|l|l|}
\hline $\begin{array}{l}\text { Vankupushidya: nkala wako } \\
\text { aumanykenge }\end{array}$ & $\begin{array}{l}\text { They kicked him out: your nkala is not famous [good } \\
\text { enough] }\end{array}$ \\
\hline Lingondo kumwambe Ankuja na dyoni & Lingondo at Mwambe He came back shameful ${ }^{20}$. \\
\hline
\end{tabular}

Magalantoni lyrics moved away from the obscure proverbial idioms that defined ngoda. More than any other wartime genre, they captured the war's everyday. Mixing of languages, a feature of migrant songs since late colonialism, was pervasive. The exotic word was culled, savoured and bent into the vernacular. No vocabulary of ready-made ideas here!

Instead of having the general experience of the war wrought into Frelimo's "courtly" symbolic net, a discrete item of military life, the warehouse, the only word in Portuguese in the song, is absorbed in the vernacular, and the experience of the institution is intertwined with the soldier's ordinary:

\begin{tabular}{|l|l|}
\hline Mboko aninguluma & A tick bit me \\
\hline Aninguluma kumagashini & It bit me in the warehouse \\
\hline Ngulinga kushapokela & I tried and pulled it out \\
\hline Ujeje kuleka popo Aninguluma kumagashini & Its head stuck there It bit me in the warehouse ${ }^{21}$. \\
\hline
\end{tabular}

On a hypnotic and melancholic melody and a slightly syncopated rhythm, elements of daily military life revolve as if in dance. The base, the communal cleaning (limpeza, practice of the socialist life in the liberated areas), the chief, the call, the collective "doing". All words are foreign, but the trace of the vernacular suffuses the song-in the conjugation of a Kiswahili verb and in overall phonetic distortion-alluding to the integration of new worlds of practice and value into domains of intimacy and feeling:

\begin{tabular}{|c|c|}
\hline Luli tupanye limpeza & In [base] Lurio, let's [make] clean \\
\hline $\begin{array}{l}\text { Chefe do campo andisema Luli tupanye } \\
\text { limpeza }\end{array}$ & $\begin{array}{l}\text { The camp chief called: "In Lurio, let's [make] } \\
\text { clean" }{ }_{22} \text {. }\end{array}$ \\
\hline Marching and miracles & \\
\hline Mwenu madyoko mukulumwiki' ambi & You, kids that grew up now \\
\hline Wetu nelo tunammyimyangidya & Today we remind-you-the-history \\
\hline $\begin{array}{l}\text { Patushitenda ing'ondo yetu kuno ku- } \\
\text { Moshambiki }\end{array}$ & $\begin{array}{l}\text { Of when we were doing our war, here in } \\
\text { Mozambique }\end{array}$ \\
\hline Patushitenda ing'ondo yetu & When we were doing our war \\
\hline Tuvenentete tundipata tabu & We-the-People, we suffered \\
\hline
\end{tabular}




\begin{tabular}{|l|l|}
\hline Yakuwena shilo na mui a-materiale & Walking day and night with [war] materials \\
\hline Tushindapangana kupagwa mashepi & We organised ourselves, to have chiefs \\
\hline Mwatupita kulamulanila & That went around commanding \\
\hline $\begin{array}{l}\text { Tushindawika kubalabala ku-kutenda } \\
\text { ing'ondo }\end{array}$ & We went to the roads to make war. \\
\hline
\end{tabular}

As we have seen, the war was sustained by the movement of people and soldiers. Many personal stories of affiliation with Frelimo began with amazing journeys: hundreds of kilometres through thick bushes, marshes, hills and rivers, fleeing from a village and joining the guerrillas across the border. War was superposed on the cognitive geography of Cabo Delgado, as the military partition of the province into four sectors became the common way of referring to its spaces. Intense movement was of course not a novelty: from ancient trade caravans to migrant labour, the history of the region was largely written by foot.

The long marches of the People carrying materials, and the complementary long marches of the leaders visiting the war zones, become the most iconic memorial trope of the Struggle, immortalised in clichés and songs. In military anthems, displacement forebodes the encounter with death. Marching is evoked through rhythm:

\begin{tabular}{|l|l|}
\hline Marere, Marere & Marere, Marere \\
\hline Tumekwenda kumbati, Marere & We went to the combat to Marere \\
\hline Tumerudi salama Marere & We returned safely from Marere \\
\hline O-o Marere & O-o Marere \\
\hline Nachingwea, Nachingwea & Nachingwea, Nachingwea \\
\hline $\begin{array}{l}\text { Tumekwenda masomo } \\
\text { Tumerudi salama Nachingwea }\end{array}$ & $\begin{array}{l}\text { We went to study/learn to Nachingwea We } \\
\text { returned safely from Nachingwea }{ }^{24}\end{array}$ \\
\hline O-o Nachingwea & O-o Nachingwea \\
\hline
\end{tabular}

30 A ngoda song, on a descending pentatonic melody, conjures some of the same tropes (marching, materials, war) in the temporality of a bone-chilling vocative:

\begin{tabular}{|l|l|}
\hline Lipililile kaka lipililile & Withstand, withstand-in-silence \\
\hline Kuka nakuja vinakubyaa & Back and forth, it will kill you \\
\hline Vyombo & Materials \\
\hline Mwambula kukuleka & Left alone in Mwambula \\
\hline
\end{tabular}


Economy, elegance and elusiveness are qualities in high esteem in Makonde orature. Things are evoked here, never said. Long marches are: "back and forth". Materials (spelled in the vernacular, not yet in the Portuguese "tropified" form) and war are brought together through parallelism and assonance. The leaving behind of the footsoldier is conjugated in an astute impersonal infinitive. The enemy is evoked in a slight change of a prefix in another parallelism: it is not things that kill (vi-), but people (va-). The verb "kupililila" (reflexive here) inscribes the suffering of War into the familiar experience of puberty rites of passage: to withstand-in-silence is what vali (initiates) learn to do when faced to the painful tests of initiation. Is it so?

While the song can be understood as relating to marches and suffering, it originally referred to a woman who had many men in different places ${ }^{26}$. The "equipment" killing her was love-rather than war-related. Men left her behind in Mwambula, because of venereal diseases. Mentioning "war" at the end of the song functioned as a reminder of the general situation in which these events occurred.

War and travelling opened up possibilities for the encounter with "the miraculous"-in Shimakonde a common metaphor for sexual promiscuity ${ }^{27}$. This magita song articulates the link quite explicitly:

\begin{tabular}{|l|l|}
\hline Biti Nkwemba & Miss Nkwemba \\
\hline Mwali biti Nkwemba & That girl, Miss Nkwemba \\
\hline Biti Nkwemba lilaja sana & Miss Nkwemba is such a whore \\
\hline Malidya mwanda & She went and travelled \\
\hline Mwanda ku-Nampula & Travelled to Nampula \\
\hline Andikadyana na camarada & To meet a comrade \\
\hline Nandanga sema: & Nandanga called: \\
\hline “Manemba mulole mambo & “You boys come and see these things \\
\hline Mulole mambo amaduvano" & These things of nowadays" \\
\hline
\end{tabular}

Marching went together with hunger. The restricted areas of war harvested little. Many survived of wild tubers, fruits, whatever. "We were living of potatoes" ("tushindanama mandumbwe"), reminds a latter song. Hunger and walking are approached here with satire rather than lament:

\begin{tabular}{|l|l|}
\hline Ku-Nshongwe Biti Nalyanga & In Nshongwe, Miss Nalyanga \\
\hline Andiva lii limo & She stole one egg \\
\hline
\end{tabular}




\begin{tabular}{|l|l|}
\hline Andyukanavo kushu & And she fled far with it \\
\hline Shilambo shaku-Memba & In the country of Memba \\
\hline Bandita anditangola & Bendita said: \\
\hline “Namwana lii leka & "Lady, leave the egg \\
\hline Andatangola mwene Panyuma, ndya' Simão" & The owner will protest Back here, Simão's wife". \\
\hline
\end{tabular}

Animals also had their part in travelling. In a remote hunting field, far from all human settlements, a mysterious house-rat appears. What is it doing there? Pointing an old witch does not seem to dispel the eeriness of the miracle (makango):

\begin{tabular}{|l|l|}
\hline Manemba nikumanya vipitile kala & $\begin{array}{l}\text { Boys, I tell you of a thing that happened a long } \\
\text { time ago }\end{array}$ \\
\hline $\begin{array}{l}\text { Ulumba wake Tamashi wetu tundyona } \\
\text { makango }\end{array}$ & In Tomas' [remote] hunting field we saw a miracle \\
\hline Tundyaka vyako vitatu wetu tushamananga & We hunted three fields, then we called everyone \\
\hline $\begin{array}{l}\text { Tunshamanila: } \\
\text { tundinkanyola }\end{array}$ & We called: "We hit a house-rat \\
\hline Apa pamimbilo" & Here at the crossroads" \\
\hline $\begin{array}{l}\text { Tundyumbala mwina nandi tunnambela } \\
\text { fundi }\end{array}$ & We met under a tree and we looked for an expert \\
\hline Tundimpata mzee Madumba audya yangele & We found the elder Madumba, the diviner \\
\hline Aninshashatanga olya wantaja nkanywa & He cut chewing tobacco \\
\hline Pamo na nula yake & Together with his medicine \\
\hline Njetu kannila maputa & And our friend accused an old lady \\
\hline Kannila maputa & Accused an old lady \\
\hline
\end{tabular}

The house-rat, though, might have its own motives to follow the guerrillas deep down in the bushes, as in this widespread ngoda song:

\begin{tabular}{|l|l|}
\hline Tummwita tuvoe nkaloni & We are many to refuse the colonizer \\
\hline Wetu tundimmwita njungu nkaloni & We refused the White colonizer \\
\hline Lingundu nkoko kutuwatika & And the house-rat followed us \\
\hline
\end{tabular}




\begin{tabular}{|l|l|}
\hline Tuvanu kutukuta kwinjia mumwitu & We ran away, entered in the bushes \\
\hline Lingundu nkoko kutulandola & And the house-rat came looking for us \\
\hline Lingondo tukammudya: & And when we asked the house-rat, [it replied]: \\
\hline Mwaa wankaloni nintamwa & “Because I refuse the colonizer \\
\hline Shilambo moshambiki ainogweleka" & Who embitters the Country of Mozambique". \\
\hline
\end{tabular}

\section{Two Coats}

"As you know. We came back from the military base and we put on a different coat (likoti)." Americo Nampindo replied with this metaphor to my question on whether he had sung both ngoda and military anthems during the war ${ }^{29}$.

The "coats" he referred to are the soldier's (mashudado) and the People's (venentete, povo) - The two groups were involved in different activities and occupied different spaces, being subjected to differing degrees to the apparatuses of the socialist State-to-be. The People carried war supplies, and lived at the outskirts of the military. In fact, the People were often metonymically referred to as "carriers of material" ("vamateriali"). Soldiers were shaped by the training and education provided in camps and bases.

A partition between the two groups' cultures was put in place, which cut through the organisation of the performance space and practices of education. Soldier's anthems were performed in spaces and situations connoted with officialdom: marches, flag-raising and generally in the camps and bases. People's songs-such as ngoda or magita-were danced "out there", in the branches and localities, in moments of informal gathering. When celebrating a recurrence, they were invited to step on the podium to represent the essence of the People under the gaze of the Leader.

Songs differed in content and form between the two groups. The heteroglossia so characteristic of migrant songs was forbidden in soldiers' songs. African languages were accepted and encouraged-together with Portuguese-but not the confusing and polysemic intermingling of languages and forms. Being "correct" did apply to grammar, as well as to the political line.

41 But songs could move from one space to the other. The farewell addressed to the beloved or the family was a common magita theme:

\begin{tabular}{|l|l|}
\hline Nangu mwanda-e malikola vangu & I go, my parents \\
\hline Ipemi yangu makono & AKM ${ }^{30}$ in my hands \\
\hline Mwanda natenda ing'ondo & I go and make war \\
\hline Na vanang'o' mwangu & With my elders \\
\hline Nangu nikapela aivé shinu & And if I die, it doesn't matter \\
\hline
\end{tabular}




\begin{tabular}{|l|l|}
\hline Ninkuvaleka vana, mwenu malikola & I leave my children to you, my family \\
\hline Vana mungushungile & Take care of my children \\
\hline $\begin{array}{l}\text { Muvatumidye vauke kushikola Vakamanye } \\
\text { kushomya }\end{array}$ & $\begin{array}{l}\text { Send them to school So that they learn to read } \\
\text { and } \text { write }^{31} .\end{array}$ \\
\hline
\end{tabular}

42 The same kind of song, stripped of all sentiment, articulated around one or two founding tropes (the People, Liberation), and rearranged by a soldier to a more martial tone could become a semi-official anthem:

\begin{tabular}{|l|l|}
\hline Nangu mwanda kwing'ondo & I go to war \\
\hline Na Ikemi yangu mmakono & AKM in my hands \\
\hline Ibalabala za ku-Shindano & On the road of Chindano \\
\hline Nikapé nangu njomba nadiva & $\begin{array}{l}\text { If I die, my [maternal] uncle will replace } \\
\text { me }\end{array}$ \\
\hline Nangu mwanda ndapela & I go to die \\
\hline Palidi lyavenentete & In the name [lit. voice] of the People \\
\hline $\begin{array}{l}\text { Liduva lyakupé nangu Shilambo shetu wetu } \\
\text { ndyambola }\end{array}$ & The day I die Our land we will free ${ }^{32}$. \\
\hline
\end{tabular}

43 Songs do offer easy ways into imagining collective subjects. A crowd sings a song. Is it expressing the crowd's inner essence, channelling its feelings? Is a song a minimal common denominator that fuses all the singing voices into a collective voice? Isn't this what anthropologists (and historians) presuppose when they read songs in order to construct cultures? Are songs a window into interiority? Or is song something more fleeting, an effect of surface? Let subjectivity be a "coat" of social relationships and personal memories, narratives, identities; a coat woven in languages, structures of feeling, habits of the body. Do songs create a fleeting fusion between the coat and the nameless nakedness that hides behind, the illusion of depth and identity? When songs rekindle memories, do they shape the present on past emotions? Does the feeling that one pours onto the songs of others testify to the human capacity for empathy and identification?

Songs articulate in a special way the ineffable with text; individuality with community; the singularity of experience with historical longue durée; memory with stimmung. The point of Nampindo's metaphor is that we do not mistake the coat for the self. And that we look at songs more as mirrors than as windows. 


\section{Heroism and Betrayal}

The year of 1968 brought crisis and upheaval in the heart of Frelimo. The facts are well known: a student revolt at the Frelimo School in Dar-Es-Salaam, the assassination of Eduardo Mondlane, the death of various main guerrillas, and an internal struggle for power between two factions, leading to the crowning of Samora Machel as leader of the movement in 1970.

The interpretations of the 1968-1969 crisis diverge along either side of the political divide. The open letter written by Frelimo vice-president Uria Simango (Gloomy situation in Frelimo) synthesises the core of Frelimo's moral crisis as one of summary executions. Frelimo's power clique disposed of political adversaries by stirring up crowds in the war zones, who would eagerly stone to death anyone who was pointed to as a traitor or a counter-revolutionary. Frelimo dismissed the letter as the voice of counter-revolution itself, expelled Simango and many others from the movement, and managed to crush the dissention. The crisis was then described as a fight between a conservative and a revolutionary line. For the losers, and those that would later take inspiration from them (Renamo), it was one between pluralism and totalitarianism.

It was only after this tormented transition that Frelimo fully embraced Leninism. The violent inscription of Utopia on the People living in the liberated zones also began during the crisis, and after the expulsion of Lázaro Nkavandame, former provincial governor of Cabo Delgado. As one interviewee said to historian Yusuf Adam, "after 1968, we all became like soldiers" (Adam 1993: 51).

One who is familiar with the moral geography of Makonde plateau knows the names and locations of the abandoned villages (madembe) where popular executions were carried out. They stand near to each Frelimo base, branch, or settlement, as a reminder of a political process "quilted" around the ritual killing of the Enemy (Israel 2009a).

Of Frelimo Aina Mwisho, the great Frelimo anthem in Shimakonde, most party militants remember only the title line, meaning: "Frelimo is endless." But the song, recorded by the Woman's Detachment choir, goes on:

\begin{tabular}{|l|l|}
\hline Simango reaccionário & Simango is a reactionary \\
\hline Nkavandame anditukuta & Nkavandame fled \\
\hline Joana reaccionária & Joana is a reactionary \\
\hline
\end{tabular}

The list of reactionaries continues, mentioning 18 names in the space of 3' 48 ".

From this official version, a verse was cut that indexes the practical usages of the song:

\begin{tabular}{|l|l|}
\hline Ukabanga vandakuduma & If you're wicked, they will punish you. \\
\hline
\end{tabular}

51 To the rhythm of this secret couplet, counter-revolutionaries and reactionaries were flogged or stoned during and after the Struggle. 
52 It is not with shame, but with self-confident pride, that Makonde contemporary political singing recalls these acts of popular justice against counter-revolutionaries. As a source of embarrassment for today's politicians, the abundance of these songs is like the symptom that refuses to be repressed:

\begin{tabular}{|l|l|}
\hline Shiashya shani shamutendile & What kind of politics did you do, you \\
\hline mapelelimo & of Frelimo \\
\hline Akumwing'a sheu Lasharo jó & of giving a chair to Lazaro, that guy, \\
\hline Nkavandame & Nkavandame? \\
\hline $\begin{array}{l}\text { Tuvenintete vamoshambiki Tulinkunjugwa } \\
\text { Lazaro Nkavandame }\end{array}$ & $\begin{array}{l}\text { We-the-People of Mozambique We want him for } \\
\text { us, Lazaro Nkavandame }\end{array}$ \\
\hline $\begin{array}{l}\text { Tukampata Lazaro jó tundantannola } \\
\text { Kenga Manduzi tundintannola Lidembe } \\
\text { kuna-Buluna }\end{array}$ & $\begin{array}{l}\text { Like Manduzi, we stoned him At the old village of } \\
\text { kuna-Buluna }{ }^{33} .\end{array}$ \\
\hline
\end{tabular}

When wearing "the other coat", and certainly before 1968, people were more tolerant of small acts of treason:

\begin{tabular}{|l|l|}
\hline Njasi & Jacinth \\
\hline Shyuventude wakuna-Nyoka & Youth of kuna-Nyoka [name of a Fre- \\
\hline & limo branch] \\
\hline Wandimandaka wakamate watoto & They sent him to catch the kids \\
\hline Watoto watoto washule & Kids, school-kids \\
\hline Njasi kati-kati amekimbia & Jacinth, in the middle of the way, he \\
\hline Kimbilia ibulanji yakunanyoka & He fled to the branch of kuna-nyoka \\
\hline Njasi Wé, minipu wé Njasi & Jacinth! Hey, what about trust, Jacinth? ${ }^{34}$. \\
\hline
\end{tabular}

54 The mythology of Heroes (vanshambelo) was also reinforced after the 1969 crisis, with the many deaths of major guerrillas, and of course, of Eduardo Chivambo:

\begin{tabular}{|l|l|}
\hline Mondlane & Mondlane \\
\hline Wakubyaite wako Vanu vamalambi & Those who killed you These people are scoundrels \\
\hline
\end{tabular}




\begin{tabular}{|l|l|}
\hline Twala & Take \\
\hline Makalatashi lao Andika & Your posters Write \\
\hline $\begin{array}{l}\text { Lina lya-Mondlane Andika Lina lya- } \\
\text { maimyo }\end{array}$ & $\begin{array}{l}\text { The name of Mondlane Write The name of History } \\
35\end{array}$ \\
\hline
\end{tabular}

With the other coat on, the People celebrated heroism in verses less iconic and more ironic. The anti-aerial gun was the key weapon of the war in its second phase, when the Portuguese dropped bombs (sometimes napalm) from aeroplanes and helicopters. The deeds of a local hero are told in a grotesquely vernacularised Portuguese ${ }^{36}$ :

\begin{tabular}{|l|l|}
\hline Luis Namajeu & Luis Namajeu \\
\hline Quando abre pogo & When he opens fire \\
\hline Caramba caramba caramba & Caramba caramba caramba \\
\hline Nossa terra pica allumado & Our land is done for \\
\hline Luis Namajeu & Luis Namajeu \\
\hline Pega arma anterea & Takes an anti-aerial weapon \\
\hline Caramba caramba caramba & Caramba caramba caramba \\
\hline Nossa terra pica alumado & Our land is done for ${ }^{37}$. \\
\hline
\end{tabular}

56 Virgilio Mbati's more modest heroism-somewhat like Jacob Zuma's ${ }^{38}$ - has to do with grabbing a machine gun:

\begin{tabular}{|l|l|}
\hline Vilijili Mbati wakuwidumbi & Virgil Mbati of Muidumbe \\
\hline Animpoka ntadola muleno & He grabbed a machine gun from a Portuguese \\
\hline $\begin{array}{l}\text { Manjolo ashindalila namene Aningupoka } \\
\text { kamalada ntadola }\end{array}$ & $\begin{array}{l}\text { The Major cried a lot: "A comrade stole my } \\
\text { machine gun!"39. }\end{array}$ \\
\hline
\end{tabular}

\section{Culture, a Weapon of Combat}

57 Song and dance were not much on the minds of Frelimo leaders during the first years of the war. There were more urgent matters to be attended to: military organisation, setting up an educational and health network in the liberated zones, and internal conflict. After the radicalization of 1969 , culture came on the agenda, with frank Leninist connotations. A series of cultural seminars was organised between 1969 and 
1973, with the objective of elaborating political directives. Culture, that is, had to become a weapon of combat, part and parcel of Frelimo's educational system ${ }^{40}$.

The "problem" posed by traditional African expression was understood firstly as one of form versus content and secondly as one of tribalism. From the formal point of view, singing and dancing were not only unharmful, but could be used to further military unity: "In song and dance we solved various problems. When we sing or dance, gestures and words are uniformed. This is the question of discipline" (quoted in Basto 2006: 128-129, 133). If the content of traditional dance had been irremediably corrupted by colonial capitalism, regeneration was in due course in the revolutionary process.

The acceptance of each morsel of "cultural practice" into the Nation was conditioned to the negation of its particularistic character:

"Today a new culture is being developed based on traditional forms with a new content dictated by our new reality. [...] culture plays an important role in the reinforcement of national unity. The dances which are performed today in the liberated regions are no longer dances of Cabo Delgado, or Tete or Niassa. The militants from other regions there bring their way of living, their dances, their songs, and from this a new culture, national in its form and revolutionary in content, is born" ${ }^{41}$.

The "liberated regions" function here as a fantasy-screen alluding to popular spontaneity:

"At night in the liberated areas the people of the villages gather by the fire and sing and dance in complete freedom, as in the time before the arrival of the Portuguese. The old people tell the children about the crimes the Portuguese practised against the people, when they occupied that territory. They tell them about episodes in the liberation struggle, the courage of our guerrillas" ${ }^{42}$.

61 The experiment of fusing together various "popular dances" to build a national identity was planned and piloted in Frelimo's military bases, and especially at the central training camp in Tanzania, Nachingwea. The new regenerated dances (with revolutionary content and open ethnic participation) were showcased in the famous "concerts" that were held at Nachingwea every Saturday afternoon (Siliya 1996: 95); or on national holidays at the bases in Mozambique, where under certain precautions, drums could be struck at their full power. "Popular dances" were thus inscribed into ceremonials of power, inspired by fascist-Leninist spectacles and not very different from their colonial counterparts. Their aesthetic organisation represented the new political order: the Leaders speech, the military parade, and on the podium the People's culture.

Choirs and guitar groups were the favoured musical expressions of soldiers, presented on Nachingwea's stage side by side with "popular dances". Partly drawing from the experience of the magalantoni, that many soldiers had sung when wearing "the other coat", guitar groups were musically influenced by Tanzanian and Congolese styles (rumba and jazz). Influent Frelimo leaders took part, in their youth, in these guitars bands.

The lyrics, however, were written "respecting the watchwords of the party. We were doing propaganda and political work, presenting the correct revolutionary line". “And you didn't sing love songs?"

"Ah, that thing of nakupenda nakupenda (I love you), that was there [...] there with the People. They sang it. We sang serious, revolutionary songs" ${ }^{43}$. 


\section{Nakupenda}

"Love poems without an explicit revolutionary content are condemnable", one of Frelimo's first documents on culture bluntly stated (quoted in Basto 2006: 130) ${ }^{44}$.

But people-as I came to know-sang about love, at least when they had the right coat on.

Distance and death rhyme with desire, as we all know. All wars have had their tunes of desperate affection. Leaving home exposes one to loss, forgetfulness, betrayal:

\begin{tabular}{|l|l|}
\hline Dada Maria-e aunalile & Sister Maria-e, don't you cry \\
\hline Nungu akalota tundakadyana & If God wants, we'll meet again \\
\hline Ata kwa-wenda lombwa, dada Maria & Even if you'll get married, sister Maria \\
\hline Aunangulivalive, nangu ni mujo & Don't forget me, me, your friend \\
\hline $\begin{array}{l}\text { Kumbukila-e manamilo letu Mwatushinamila } \\
\text { maduva panyuma }\end{array}$ & $\begin{array}{l}\text { Remember our way of life How we used to live } \\
\text { in the old days }\end{array}$ \\
\hline
\end{tabular}

67 The influence of foreign urban music and its languages was important in the upsurge of this wartime sentimentalism. Not by chance, desire was spelled in (vernacularised) Kiswahili:

\begin{tabular}{|l|l|}
\hline Nishalau & I had forgotten \\
\hline Uko kwetu Makonde & Here, our Makonde lands \\
\hline Kuja bondeni kulima samba & I go to the lowlands to work a chamba [field] \\
\hline Kina dada wote tulime samba & You, sister, let's work a chamba \\
\hline Samba landise tupate mali & A chamba of bananas, to make some money \\
\hline Filomena, dada Filomena & Filomena, sister Filomena \\
\hline Filomena nakupenda & Filomena, sister, I love you ${ }^{46}$. \\
\hline
\end{tabular}

Not only is the soldier worried about leaving behind a wife to the seductions of his friends. War sucks up the better years of one's life, those blessed with fecundity. The lack of means does not enable one to satisfy the desires of modern girls:

\begin{tabular}{|l|l|}
\hline Wako njomba aunatangadike namene & Hey, uncle don't be angry \\
\hline Si nangu mwiu ndalomba & I am going to marry, really! \\
\hline Nindivakodya vatatavao & I met their [the girls'] fathers \\
\hline
\end{tabular}




\begin{tabular}{|l|l|}
\hline Vapakanila kushi doni: & And they were discussing, like this: \\
\hline "Tundivadoba kuvashumila dinguvo & "We are tired of buying them cloths \\
\hline Ava vali vasasa nimpomo" & These girls of nowadays it's worse" \\
\hline
\end{tabular}

Love invaded wartime songs not only because of distance and fashions. Frelimo aimed at the radical transformation of gender and power relationships. The law of socialism had to substitute for custom. Affection was an angle to discuss these new forms of "moral subjectivation" (Foucault 1984: 33-45): the shaping of a relationship between an individual and the Law, the interiorisation of a norm into one's daily practice.

\begin{tabular}{|c|c|}
\hline Namwita vaninshema & They called Namwita (I-will-refuse) \\
\hline Vaninshema valikola & Her family called her \\
\hline Pakulota vantamedye & To make her move [in order to marry] \\
\hline Namwita akandipinga & Namwita shook her head \\
\hline Vandigombana sana pakummwita & The fought hard when she refused her \\
\hline mwana njomba & [maternal] uncle's son \\
\hline Namwita maduvano & Namwita these days \\
\hline Ankwikala gweka yake & Sits all by herself \\
\hline Pakunshunga sherikali & The government is taking care of her \\
\hline Valikola vaninjaa & Her familiars abandoned her \\
\hline Shitadidye vakanjae & What made them abandon her \\
\hline $\begin{array}{l}\text { Vandigombana sana pakummwita mwana } \\
\text { njomba }\end{array}$ & $\begin{array}{l}\text { They fought hard when she refused the uncle's } \\
\text { son }\end{array}$ \\
\hline Kaka Namwita kutikinanga disharia & Namwita's brother doesn't know the laws \\
\hline Disharia dyashinyakala dindinyata & The laws of old are ugly \\
\hline Numbuwo mwanao a-njomba wako & Your sister, the daughter of your mater- \\
\hline kunshema ndyao & nal uncle, you call her "my wife" \\
\hline Munkukowa & You are doing wrong. \\
\hline
\end{tabular}
intended effects. When moral subjectivation goes all wrong, when appearances betray 
the eye and the heart, when the weekly routine starts with the wrong foot, the exotic names of socialism's institutions turn into sites of shame and exposure:

\begin{tabular}{|l|l|}
\hline Ava vali ni vali & These girls these girls \\
\hline Amunavone kwalala & Don't see them [as] beautiful \\
\hline Amunavone kunyeta & Don't see them [as] fatty \\
\hline Vandyalibika kasende & They are broke by gonorrhoea \\
\hline Jumatatu 'kawika & When Monday comes \\
\hline Kutwalananga shipinga & You take all your group \\
\hline Kulangalela indila Kushipitali Zambézia & And you lead the path To the Zambézia hospital ${ }^{47}$. \\
\hline
\end{tabular}

MUIDUMBE JAZZ WAS A FAMOUS LOCAL MAGITA GROUP IN THE LATE 1970S. LUIS PAULO LIPASHULE "JUNTA", AT THE DOORPOST, OVERSEES THE PROGRESSES OF THE GROUP THAT HE HAS RECENTLY REVIVED, MUIDUMBE, 2009 (RUI ASSUBUJI)

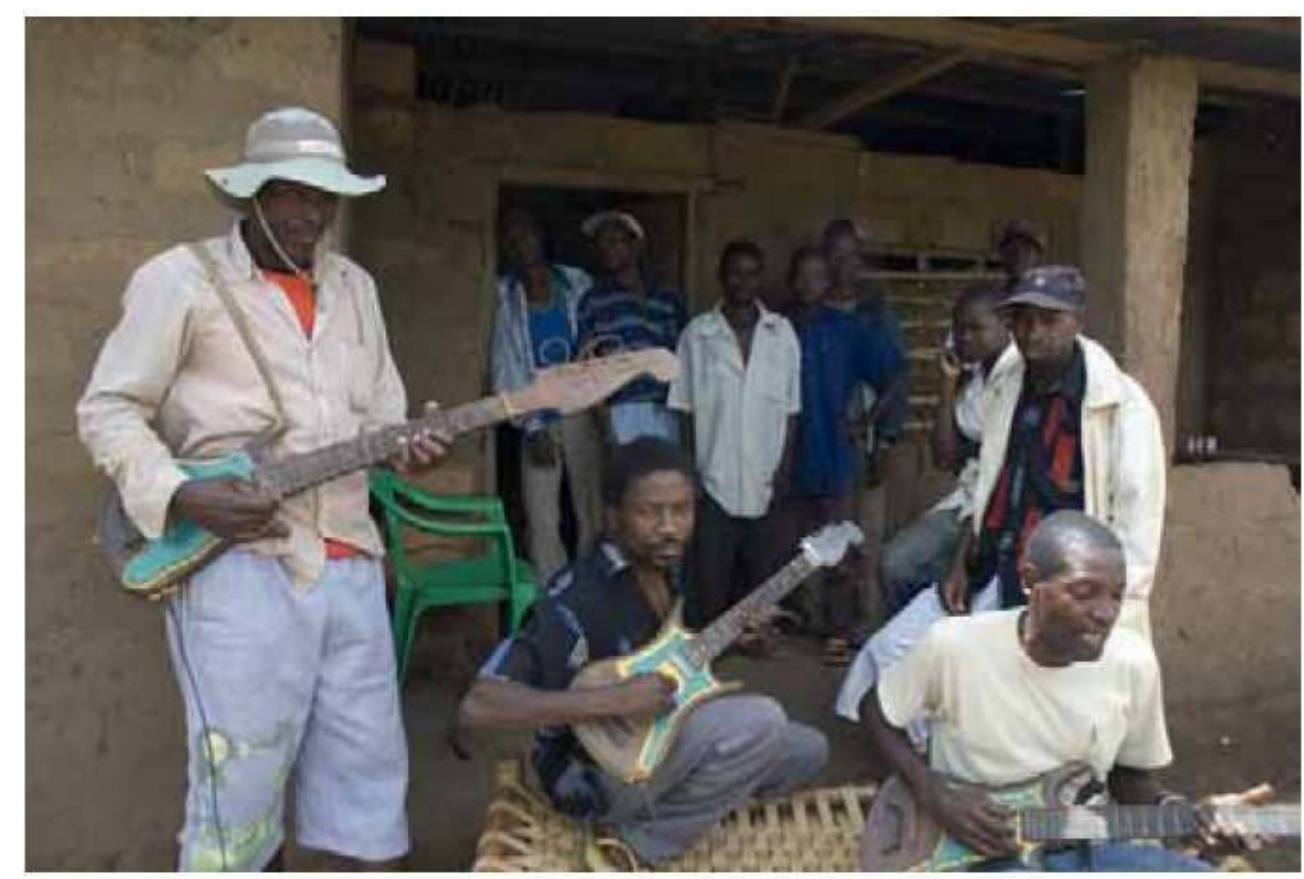

\section{Arriaga and Teleology}

\begin{tabular}{|l|l|}
\hline Nakulailila mwenu menentete & Now, as a farewell, you People [I say:] \\
\hline Tenda ing'ondo na ntima wou & Make war with this same heart \\
\hline $\begin{array}{l}\text { Patime panatime akuno Moshambike } \\
\text { tundapata Uhuru }\end{array}$ & $\begin{array}{l}\text { It might take time, in Mozambique we will } \\
\text { receive Independence }\end{array}$ \\
\hline
\end{tabular}




\begin{tabular}{|l|l|}
\hline Kuma Rovuma mpaka ku-Maputo & From the Rovuma to the Maputo \\
\hline Tuvenentete tundyuka na igwana & We the People, we have come together \\
\hline $\begin{array}{l}\text { Tunditenda ing'ondo ya myaka kumi mpaka } \\
\text { tundyambola }\end{array}$ & We made the Ten-Year-War, until we liberated ${ }^{48}$. \\
\hline
\end{tabular}

71 The Struggle had two major, long lasting ideological legacies. One, as we have seen, was the concept of "the People". The second was a concept of teleology. Based on a secularisation of Judeo-Christian time, a teleological reading of history is at the core of what we call modernity (Koselleck 1990). It is also a central concept of revolution, where victory and socialism are synonymous and inevitable. This concept of history as a meaningful and progressive order was absent from Makonde singing (and cosmology) before 1960 .

The dramatic events of 1971 provided a tangible ground for a vision of victorious teleology. In that year, the Portuguese stroke back at Frelimo with an operation that was intended to wipe out the military bases of the movement, and bring all "natives" back under control. Code-named "Gordian Knot" ("Nó Górdio"), the operation set to "comb the bushes" with might and violence, accompanied by propaganda falling from the skies and filling the ether. General Kaulza de Arriaga, who had learnt his lessons in Vietnam, was in command (West 2005: 145-147). Gordian Knot brought sufferings and disruption. Chains of command were broken. Bases abandoned. Guerrillas groups hit independently, with the only objective of surviving and bringing losses to the enemy. Lament and menace seemed the appropriate voice:

\begin{tabular}{|l|l|}
\hline D’Aliyaga malidya mwanda wende kwenu & Arriaga, leave and go to your own country \\
\hline Venintete vandikudoba kukubyaa Ariaga & The People are tired of killing you, Arriaga \\
\hline $\begin{array}{l}\text { Myadi vyako ku-Moçambique ivé matanda loe } \\
\text { Aliyaga }\end{array}$ & $\begin{array}{l}\text { In Mozambique, your blood is like lagoons } \\
\text { Arriaga }^{49} .\end{array}$ \\
\hline
\end{tabular}

72 Gordian Knot turned out to be a disaster. The expenditure on the operation was huge. Frelimo resisted. Kaulza went back with his tail behind his legs. This defeat of the colonial army was the first major readable sign of a historical teleology, and the symbolic matrix of all successes to come. The inevitable victory of the future resembles the victory already harvested in the past:

\begin{tabular}{|l|l|}
\hline Paidi' Lyaga tuvenentete kuva & $\begin{array}{l}\text { When Arriaga came, We-the-People we } \\
\text { suffered }\end{array}$ \\
\hline Makapatela muwa dikatapila pai & Helicopters up, caterpillars down \\
\hline Vapita valimanga dibalabala dya-ing'ondo & Going around digging the roads of war \\
\hline Tuvenente anditukodya tuvenneo & But he found Us-the-People ready \\
\hline
\end{tabular}




\begin{tabular}{|l|l|}
\hline Tunditenda ing'ondo mpaka Aliaga & We did the war until he went home \\
\hline $\begin{array}{l}\text { andyuka kwao Tukava wetu shimbili } \\
\text { shinduymanga }\end{array}$ & As for ourselves, we got famous ${ }^{50}$. \\
\hline
\end{tabular}

War was no longer the setting for topical singing. Struggle became the subject matter of historically-oriented compositions, called "songs of reminding" (dimu dya kwimyangidya).

74 After the successful resistance to Gordian Knot, Frelimo tightened its grip over the liberated zones. The Portuguese seemed weaker, the guerrillas stronger, and the helicopters farther away. The veil of silence over drums was finally lifted. Dances came back to Makonde country with their intrinsic loudness. The two "drums" that had protagonised the years of silence -ngoda-rattles and magita-zithers-were replaced with powered versions. Ngoda was transformed into limbondo, a drummed circular dance where people dress in tatters, wear animal-fur backpacks and violently shake axes or scythes. Although some of the old songs "transited" into the new versions, most of those that referred to the experience of the war were abandoned. Morality was a thread that passed onto limbondo:

\begin{tabular}{|l|l|l|}
\hline $\begin{array}{l}\text { Kwiva kundinyata Twa' shipula } \\
\text { kummwing'a mwene }\end{array}$ & $\begin{array}{l}\text { Stealing is ugly [bad] Take the knife and give it } \\
{[\text { back] to the owner }}\end{array}$ \\
\hline $\begin{array}{l}\text { Liduva lya vakwona vene Kwiva } \\
\text { kundapwateka Kwiva amunavalele }\end{array}$ & $\begin{array}{l}\text { The day that the owners see you Stealing will } \\
\text { hurt Don't get used to stealing! }{ }^{51} .\end{array}$ \\
\hline
\end{tabular}

Zithers such as magita and magalantoni were all but abandoned. Many people went on to play home-made electric guitars (also called magita). People' groups imitated the "correct" political style of soldiers, while also continuing to sing love songs. Their "history" sometimes sounded empty:

\begin{tabular}{|l|l|}
\hline Manemba mwangu nelo ninnamanyia & My boys, today I tell you \\
\hline Mauvilo atupati' mwing'ondo & How we suffered during the war \\
\hline $\begin{array}{l}\text { Vitendo vyoe vyatutandeke wetu Mumyaka } \\
\text { kumi vya twike' mwing'ondo }\end{array}$ & $\begin{array}{l}\text { The many things that happened to us In the } 10 \\
\text { years that we passed in war }{ }^{52} .\end{array}$ \\
\hline
\end{tabular}




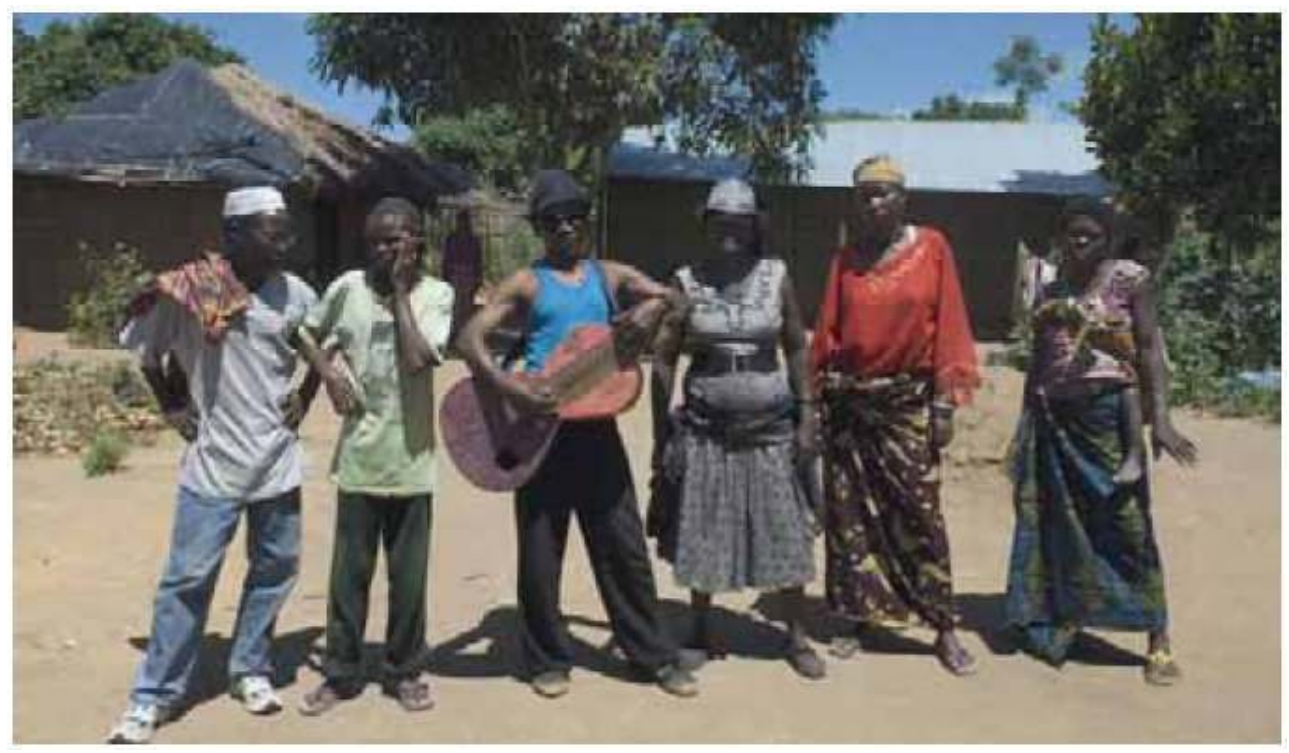

\section{Tropes of Utopia}

After Gordian Knot, increasingly "cultural activities" took place in the schools, on the model of those organised in the military camps. Pupils would mostly learn choral songs, and a few selected popular dances. As Frelimo educational centres (centros pilotos) were placed in the proximity of a military base, to defend the children from possible incursions, school pupils grew up with soldiers, and were subjected to military rules, routines and ceremonials. Choral songs were only partly taken from the military repertoire: a whole set of educational songs were composed, that set to instil revolutionary values, political consciousness and historical memory. The texts were structured around a trite recitation of ideological formulas, dates, and names of heroes and leaders.

In the final years of the war (possibly 1973), the dance makwaela became the elective cultural activity for pupils in Frelimo schools. This is a southern Mozambican variant of a region-wide modality of choral singing, makwaya (from the English "choir"), where European four-part harmony is fused with local musical practices such as "responsorial organisation, dense overlapping, and variation of individual parts [...] more relaxed vocal timbres, a more spontaneous approach to vocal exclamations and other sounds" (Turino 2000: 125). Its origins in migrant labour (especially from southern Mozambique to South Africa) gave it the right credentials of a revolutionary dance. Simple and rhythmical, it appeared ideal for schools and ideological work. In the years after independence makwaela became the national school-dance, and one of the major forms of transmission of the Party's slogans. Hundreds of tapes of makwaela songs were recorded in a national campaign between 1976 and 1978, in the pilot schools.

Makwaela also became the main form of dance taught to Makonde boys and girls at initiation rituals, and the one that they would present to the village at the rites' comingout. The slogans and formulas of the Party were considered to be the central values instilled in the men and women to be (Israel 2006: 113): 


\begin{tabular}{|l|l|}
\hline Povo Moçambicano & Mozambican People \\
\hline Na marcha para Liberdade & In the march for Freedom \\
\hline Da economia nacional & Of the national economy \\
\hline Devemos centralizar (nos avanços) a & We must centralize (in the advance- \\
\hline produção & ments) the production \\
\hline Base da Economia Nacional & Base of the national economy \\
\hline Devemos sincronizar (nos avanços) a & We must synchronise (in the advance- \\
\hline produção & ments) the production \\
\hline Base da Economia Nacional & Base of the national economy \\
\hline Revolução Moçambicana & Mozambican Revolution \\
\hline E o futuro de Moçambique & Is the future of Independent \\
\hline Independente & Mozambique \\
\hline E' a produção & Is production \\
\hline Congresso da Frelimo & The Frelimo congress \\
\hline Reúne e traça planos & Meets and traces plans \\
\hline Para o avanço & For the advancement \\
\hline Da producção & \\
\hline
\end{tabular}

79 Pier Paolo Pasolini, elaborating on a much older construct of romantic philology, uses the metaphor of falling down (precipitare) to describe the movement of descent of aesthetic practices from courtly poetry into popular oral poetry-the verticality of the metaphor indexes relations of power (Pasolini 2006: 38). Pasolini shows how figures of style and consolidated literary formulas elaborated by courtly poets (especially in Sicily in the $13^{\text {th }}$ century) were appropriated by the popular poets in the form of fragments, endowed with a certain stiffness, like foreign bodies captured in a process of mineral sedimentation. There, they would thrive and survive for centuries, protected by the courtly aura embedded in their formal composition. Similarly, ideological formulas elaborated in Frelimo's "courtly" music, composed under direct ideological control, "fell”, or "trickled down" into the popular dances that were enlisted in the project of the Nation, in the form of fragments, and into the texture of consolidated forms of textual composition. And there they stuck, as ready-made tropes of a new stereotyped vocabulary. Domination (kutawala), servitude (utumwa), colonial taxes (ukoti), forced labour (shibalo), the lamentation (tundipata tabu), the ten years (myaka kumi) of war (ing'ondo), the carrying 
of military materials (materiale, Pt.), the leaders (machepi), the organisation (kupangana), understanding (igwana), unity (upamo), the long walking (kuwena shilo na mui), the blood spilled (myadi), the geographical metonym of national unity (kuma Rovuma mpaka kuMaputo), the quasi-messianic expectation (patime panatime), the roads (ibalabala), heartcourage (ntima), the invocations to the leaders (mwenu manang'olo), perseverance (kukanyilidya), the Party (ishama), the rejoicing (kupuwa), the expelling of the colonialists (kuusha), the recitation of dates (italee)... And of course We-the-People (tuvenentete) ${ }^{54}$, revolution (mapindushi), independence (Uhuru), and liberation (kwambola) ${ }^{55}$.

When watchwords from Frelimo courtly literature began to trickle down into Makonde orature, articulate expressions of political "protest" disappeared therein. Lament was produced as a codified trope. Kulila kwatulila-we cry and we cry-for colonialism, oppression, the deaths of leaders (and more recently for absolute poverty, AIDS...). Metaphor, irony and complexity were the victims of this process of tropification. Song production in Shimakonde-the one that Makai was describing-registers a sharp, almost quantitative decrease of rhetorical strategies such as metaphor, ellipsis and idiophones in coincidence with the peak of Frelimo's utopian project, and in the genres that were mostly involved in the Struggle, and a sudden reappearance of these linguistic devices in subsequent genres ${ }^{56}$.

From a rhythmical point of view, nationalised "popular dances" often maintained the aspect that they had before the Revolution. Visual imagery referring to the Party was massively introduced: flags, images, tissues and masks depicting leaders, weapons such as AKM, grenades, bazookas...57. A number of genres were most neatly identified with nationalism and the Party, and benefited from increased prestige and popularity.

Other genres of dances and songs simply disappeared, as they did not conform to the ideological requirements of the Party. This is the case with the "songs of provocations" that Makai refers to as the songs of "middle-times" (roughly, late colonialism), where dance groups of different lineages exalted and insulted each other, often resulting in violent confrontations. Far from being the predominant genre of the late-colonial Makonde song production, these songs found their raison d'être in the schismogenetic logic of pre-colonial Makonde segmentary society, embedded in the disruptive networks of slave trade. As the Party explicitly prohibited them as a form of "tribalism", they swiftly vanished, only to resurface years later as electoral songs in the times of the multiparty system (Israel 2006: 120-121).

\section{History To Be Reminded}

\begin{tabular}{|l|l|}
\hline Tulivaliva & We must not forget \\
\hline Myaka kumi vy'ing'ondo & Ten years of war \\
\hline Tunditenda & We carried it out \\
\hline Kumoshambiki indyambola & We liberated Mozambique \\
\hline Tundishumba & We passed \\
\hline Vyakunannopa namene & Many hard things \\
\hline
\end{tabular}




\begin{tabular}{|l|l|}
\hline Myaka kumi & Ten years \\
\hline Kumoshambiki indyambola & We Liberated Mozambique. \\
\hline
\end{tabular}

The songs that play the lion's part in this piece-good music that you, reader, are unable to listen, and this paper, alas, is unable to sing-belong to genres and repertories foregone or forgotten. It is during a recording session with Samuel Mandia in Mueda towards the end of my doctoral fieldwork (2005) that I learned for the first time about the existence of the magita wartime genre. A master of the zither, Mandia is known in the province for his songs called bwarabwà-a genre of social critique danced at funeral ceremonies, which he has re-adapted. While playing for me bwarabwà pieces, Mandia came up with one or two oldies, played and sung in a completely different style. He told me that they were part of a genre sung during the war, that no one would play anymore. These old wartime tunes-he told me-were not requested or appreciated anymore, although one or two could occasionally be slipped in during a performance. I was later able to locate four more performers of magita songs. Many other people told me that they had played the instrument, but had then forgotten everything. As to ngoda, I also came across this dance by chance. No one practices anymore, and only a few groups could struggle to remember songs. None of these songs is preserved in any of the Radio Moçambique archives, which hoard hundreds of makwaela tapes, and many Makonde "revolutionary songs". However, as this paper hopefully has shown, it is precisely these genres of songs that convey some splinters of "live memory" of the Struggle.

In 2008, following an indication of Mandia, I was able to record Fiel Liloko's magita songs. When I asked Liloko to play wartime songs, he instead started play songs about the war, composed after Independence, and deeply influenced by Frelimo's vocabulary. While clarifying the misunderstanding, Liloko referred to the new compositional mode about the war as dimu dya kwimyangidya. The verb "kwimya" means (something like): "To tell a story in order to remember it." Its durative-causative form "kwimyangidya" 58 thus means: "To remind (intensively, repeatedly) a history that should be remembered." Maimyo, a substantive derived from kwimya, is usually simply translated as "history", but conveys the same notion of "history to be reminded".

Gramsci defined "popular culture" (folklore) as embedded in a structure of class, articulated around a "common sense", mostly religious, and characterised by the incorporation of scientific discourse produced by the elites in the form of fragment ${ }^{59}$. Similarly, the idiom of "Makonde revolutionary singing" ("dimu dya mapindushi"), like a clastic rock, coalesced around inert fragments of Frelimo's discourse of scientific socialism: watchwords, dates, events, names, actions, tropes. The temporality of teleology (the vanquished past as the matrix for the future to come) was the major compositional mode adopted from Frelimo's "courtly" productions. The fragments of Frelimo's "dictionary of ready-made ideas" took such an authoritative position not simply because of coercion, but by way of a collective libidinal investment in the project of the People. In Mueda, this amounted to taking up the name that one has been given, to assuming onto oneself the prestigious myth-history of the Struggle. We-the-people (tuvenentete), and "the liberators" ("tundyambola") are the subjects responding to this interpellation. Taking up new songs of "reminding" ("kwinyangidya") and forgetting old wartime genres was part of the response. 
The thematic core of Makonde political singing was constituted around a concept of history-to-be-reminded (maimyo), in which the deeds of the Struggle were sung as they were supposed to have enfolded:

\begin{tabular}{|l|l|}
\hline Shumbo shitandi shindyuma & The first lead was discharged \\
\hline Iboma yakushai & At the district of Chai \\
\hline Kulangalela kaka Chipande & The leader was our big brother Chipande \\
\hline Pamo na vavagwe & With his friends \\
\hline Tundamanya mavetu & We inform you, my friends \\
\hline Mwenu mukapagwite & You who were not there \\
\hline Mwatulyadile ndugu pachai & How we organised our plan in Chai \\
\hline We' tunamanya & We inform you \\
\hline Tundintuma njetu Chipeda & We sent our friend, Shipeda \\
\hline Wena palalesha & Go, and spy! \\
\hline Palidimbile liduva & When the evening got dark \\
\hline Wetu tundinjila & We entered. \\
\hline
\end{tabular}

This contemporary mapiko choir describes the mythic beginning of the Liberation Struggle, the "first lead" shot by Joaquim Alberto Chipande, Makonde guerrilla who then would make its way to be Minister of the Defence. While the story is indexed in a firstperson plural (wetu), it actually does not map any direct experience. In the account of the first shot, authored by Chipande himself and published in Eduardo Mondlane's The Struggle for Mozambique (1969) the identity of the person whom famously Chipande sent to espionage the post of Chai, wrapped in bandages, was misattributed. The spy wasn't Bento Chipeda, but Bento Pachihi Nalyambipano. The mistake was later rectified in the official record ${ }^{60}$, but not in the "popular" text, which tells the story by the (old) book. In Makonde plateau, the idiom of "revolutionary songs" was put to various social usages. Memorialisation at a national level echoed local competitions for symbolic capital, or cultural prestige-the more revolutionary, the better:

\begin{tabular}{|l|l|}
\hline Tuvalole vala & Look at those \\
\hline Muvaimbanga dimu dyabwarabwà & You, who sing bwarabwà songs \\
\hline Muvé nadyoni & You are shameful \\
\hline Kanji wetu twigilila & But us, listen to us \\
\hline
\end{tabular}


Wetu kwimbanga dimu dyamapindushi Kanji wetu twigilila
We sing revolutionary songs But us, listen to $\mathrm{us}^{61}$.

\section{BIBLIOGRAPHY}

ADAM, Y., 1993, “Mueda, 1917-1990: resistência, colonialismo, libertação e desenvolvimento", Arquivo, Boletim do Arquivo Histórico de Moçambique 14: 4-102.

AMSELLE, J.-L., 2008, L'Occident décroché. Enquête sur les postcolonialismes (Paris: Stock).

APTER, A., 2002, "On Imperial Spectacle. The Dialectics of Seeing in Colonial Nigeria", Comparative Studies in Society and History 44 (3): 564-596.

BAKHTIN, M., 1965, L'œuvre de François Rabelais et la culture populaire au Moyen Âge et sous la Renaissance (Paris: Gallimard).

BARBER, K., 1987, “Popular Arts in Africa”, African Studies Review 30 (3): 1-78.

BARBER, K. (ed.), 1997, “Introduction”, Readings in African Popular Culture (Bloomington: Indiana University Press; Oxford: Currey): 1-12.

BASTO, M.-B., 2006, A Guerra da Escritas. Literatura, Nação e Teoria Pós-Colonial em Moçambique (Lisboa: Vendaval).

BRINGMAN, I., 2001, Singing In the Bush. MPLA Songs during the War for Independence in South-East Angola (1966-1975) (Köln: Rüdiger Köppe).

CAHEN, M., 1999, “The Mueda Case and Maconde Political Ethnicity. Some Notes on a Work in Progress", Africana Studia 2: 29-46.

CIRESE, A. M., 1977, “Gramsci e il folklore come concezione tradizionale del mondo delle classi subalterne", Problemi 49: 155-167.

COPLAN, D., 1993, "History is Eaten Whole: Consuming Tropes in Basotho Auriture", History and Theory 32 (4): 80-104.

- 1994, In The Time of Cannibals. The Word Music of South Africa's Basotho Migrants (Chicago-London: University of Chicago Press).

COPLAN, D. \& JULES-ROSETTE, B., 2008, “'Nkosi Sikelel iAfrika': Stories of an African Anthem”, in G. OLWAGE (ed.), Composing Apartheid. Music for and Against Apartheid (Johannesburg: Wits University Press): 185-208.

DEPELCHIN, J. \& DE BRAGANÇA, A., 1988, "From the Idealization of Frelimo to the Understanding of the Recent History of Frelimo", Review 11 (1): 177-178.

FABIAN, J., 1996, Remembering the Present: Painting and Popular History in Zaire (Berkeley-Los Angeles: University of California Press). 
- 1998, Moments of Freedom: Anthropology and Popular Culture (Charlottesville: University Press of Virginia).

FOUCAUlt, M., 1984, L'Histoire de la sexualité, II: L'usage des plaisirs (Paris: Gallimard).

GEFFRAY, C., 1988, “Fragments d'un discours du pouvoir (1975-1985)”, Politique africaine 29: 71-85.

- 1990, La Cause des Armes au Mozambique. Anthropologie d'une guerre civile (Paris: Karthala).

GOMEs, M. B., 1999, Educação Moçambicana. História de Um Processo, 1962-1984 (Maputo: Livraria Universitária da UEM).

GRAMSCI, A., 1982, Folclore e senso comune (Roma: Editori Riuniti).

GUNDERSON, F. D. \& BARZ, G. F. (eds.), 2000, Mashindano! Competitive Music Performance in East Africa (Dar-Es-Salaam: Mkuki na Nyota).

GUNNER, L., 2009, "Jacob Zuma, the Social Body and the Unruly Power of Song”, African Affairs 108 (430): 27-48.

HIRSCH, J., 2003, Amandla! A Revolution in Four-Part Harmony (Lions Gate Film).

ISRAEL, P., 2006, “'Kummwangalela Guebuza', The Mozambican General Elections of 2004 in Muidumbe", Lusotopie 13 (2): 103-126.

- 2008, Masques en Transformation. Les performances mapiko des Makonde (Mozambique). Historicité, création et révolution, Thèse de doctorat (Paris: EHESS).

- 2009a, "The War of Lions. Witch-Hunts, Occult Idioms and Post-Socialism in Northern Mozambique", Journal of Southern African Studies 35 (1): 155-174.

- 2009b, "Utopia Live: Song and the Liberation Struggle in Mozambique", Kronos. Journal of Southern African Histories 35: 98-141.

KOSELLECK, R., 1990, Le Futur passé: contribution à la sémantique des temps historiques (Paris: Éditions de l'EHESS).

KUBIK, G., 1981, “Neo-Traditional Popular Music in Africa since 1945”, Popular Music 1: 83-104.

LACLAU, E., 2005, Critique of Populist Reason (London: Verso).

LEFORT, C., 1986, The Political Forms of Modern Society (London: Polity Press).

MAZULA, B., 1995, Educação, Cultura e Ideologia em Moçambique 1975-1985 (Porto: Afrontamento).

MONDLANE, E. C., 1969, The Struggle for Mozambique (London: Penguin African Library).

PASolini, P. P. (ed.), 2006, "Introduzione”, in Canzoniere Italiano. Antologia della Poesia Popolare (Milano: Garzanti).

PONGWENI, A. J. C., 1997, “The Chimurenga Songs of the Zimbabwean War of Liberation”, in K. BARBER (ed.), Readings in African Popular Culture (Bloomington: Indiana University Press; Oxford: Currey): 63-72.

SERRA, C., 1997, Novos Combates Pela Mentalidade Sociológica (Maputo: Livrária Universitária da UEM).

- 2003, Combates Pela Mentalidade Sociologica (Maputo: Livrária Universitária da UEM).

SILIYA, C., 1996, Ensaio sobre a cultura em Moçambique (Maputo: CEGRAF).

THIONG'O, N. WA, 1997 “Enactments of Power: The Politics of Performance Space”, TDR 41 (3): 11-30. 
TURINo, T., 2000, Nationalists, Cosmopolitans and Popular Music in Zimbabwe (London-Chicago:

Chicago University Press).

VAIL, L. \& WhITE, L., 1991, Power and the Praise Poem, Southern African Voices in History

(Charlottesville: University Press of Virginia).

VIEIRA, S., 1978, “O homem novo é um processo", Tempo 398: 27-38.

WEST, H. G., 2005, Kupilikula. Governance and the Invisible Realm in Mozambique (Chicago-London:

Chicago University Press).

ZAWANGONI, S. A., 2007, A Frelimo e a formação do Homem Novo (1964-1974 e 1975-1982) (Maputo:

Livraria Universitaria).

ŽIŽEK, S., 2008, For They Know Not What They Do. Enjoyment as a Political Factor (London: Verso).

\section{NOTES}

1. On the mythification of Frelimo and the Liberation Struggle, see amongst others the pioneering article of DEPELCHIN and DE BRAGANÇA (1988), C. SERRA's work on "samorism" (2003: 27-33) and "frelimism" (1997: 95-112) and M. B. вАSTO's research on the literary construction of the Nation during the Liberation Struggle (2006).

2. Once a district of the Mozambican Colony, Cabo Delgado is now the northernmost of Mozambique's twelve provinces, bordering with Tanzania on the North and with the Indian Ocean to the East, and situated at about 2,500 km from the capital, Maputo.

3. In this article I present mostly songs that were performed during the war of liberation, from a corpus of around 150 songs. I draw comparative insights from an overall corpus of over a thousand songs in Shimakonde and Kiswahili. I have recorded live performances in Cabo Delgado (districts of Muidumbe, Mueda, Nangade, Macomia, Mocimboa da Praia and in the city of Pemba), and retrieved songs at the archives of Radio Moçambique, Maputo and Pemba; ARPAC (Arquivos do Património Histórico e Cultural), Maputo, Pemba, Chimoio; audio-visual archives of the Companhia Nacional de Canto e Dança, Maputo.

4. It can also be argued that the marking of certain genres as "popular" in academic discourse is based on the same operation that defines a populist politics. This argument -that I defend elsewhere-is outside of the purview of the present article.

5. "It is not difficult to see how all radical revolutionary projects, Khmer Rouge included, rely on this same fantasy of a radical annihilation of tradition and of the creation ex nihilo of a New (sublime) Man, delivered from the corruption of previous history" (žıžEK 2008: 261).

6. "The question is, for the comrades of Utopia, of making a blank slate of the past, of detraditionalising colonialism and de-colonizing tradition" (SERRA 1997: 97), my translation.

7. The understanding of Frelimo's politics as one of populism was indeed the major insight of Christian Geffray's path-breaking (and misunderstood) research on the roots of the Mozambican civil war (GEFFRAY 1988, 1990).

8. The two go together. A "drum" is called a "drum" even when it features no drumming: for instance when singing is accompanied by rattles or other musical instruments. Often the name "drum" refers also to initiation. 
9. Competitions between dance groups are a feature of the East African cultural landscape (GUNDERSON \& BARZ 2000).

10. Magita song, Samuel Mandia (Mueda: recording session, July 2008). "This chairman really existed", recounted to me Samuel Mandia, laughing. "He used to chair the branch of Ntumbati. And he would do meetings and tell us that the Portuguese would soon surrender and concede Independence."

11. Ngoda song, Americo Nampindo's group (Myangalewa: recording session, September 2004).

12. Ngoda song (Nampanya: recording sessions, December 2004 and April 2009).

13. Ngoda song (Namakule: recording session, January 2005).

14. For a comparative glance on other Struggle anthem traditions in Southern Africa, see amongst others PONGWENI (1997), TURINO (2000), BRINGMAN (2001), HIRSCH (2003), COPLAN \& JULES-ROSETTE (2008).

15. The three others were Simão Tiburcio Lindalandolo, Calisto Mijigo and Abílio Filipe Awendila. They had passed away at the time of my fieldwork (2002 on). I interviewed Zaaqueu in February 2005 in his house in Pemba. Recordings of his songs are kept at the ARPAC in Maputo. Zaaqueu is also the author of collections of poems. Another important literate composer that I worked with in Pemba is Manuel Gondola, with whom I had the privilege of playing in a short-lived band (2002).

16. This is Zaaqueu's. He sang it for me, but the song is well known and it appeared in booklets and collections.

17. Magita song, Samuel Mandia (Mueda: recording session, 2008). "Raimundo" refers to Pashinuapa, important Makonde Frelimo leader.

18. This is the local name of a musical instrument played in East Africa, especially in Tanzania (kipango), Mozambique (also bangu, bancu, iwaya, etc.) and Malawi (bangwe), that ethnomusicologists call "board-zither". It is made of a wooden board, on which a long wire is stretched, in such a way as to produce five, six or seven strings. It is strummed or fingered. The instrument underwent a major "modernisation" on a regional scale already in the late 40 s, when many musicians adopted playing styles inspired by guitars. The American "banjo" (or at least its name) could be a descendent of this instrument ( KUBIK 1981).

19. Samuel Mandia (Mueda, recording session, January 2005).

20. Samuel Mandia, ibid.

21. Samuel Mandia, recording session (Mueda: July 2008).

22. Samuel Mandia, ibid.

23. Fiel Liloko (Shinda: recording session, August 2008).

24. Studying is as dangerous an activity as combat. The relationship between the twothe question of students going to the front, and the politicisation of education-were harshly debated during of the 1968-1969 crisis (see further).

25. Ngoda (Nampanya: recording session, December 2004).

26. So the authors explained to me during an interview (Nampanya, March 2009). I wrote the commentary to the song before that, and I believe it still stands. This testifies to the potential polysemy of the song.

27. Kulava, a miracle; kulavalava, having many lovers. 
28. Samuel Mandia, ibid.

29. A. Nampindo (Myangalewa: interview, April 2009).

30. AK49, the machine gun.

31. Magita song, Fiel Liloko (Shinda: recording session, August 2008).

32. Magita song, Samuel Mandia (Mueda: recording session, January 2005).

33. Mapiko song, Nandindi group (Mwambula: recording session, March 2005). Nkavandame had long been dead when the song was composed. Mandusi, a local sipaio, was stoned in 1974 near the village of Miteda, and thence stood as the epitomic figure of popular justice. Kuna-Buluna was one of the madembe were people would be killed.

34. Magita song, Samuel Mandia (Mueda: recording session, January 2005).

35. Mapiko song, Omba (Mueda: live recording, June 2003).

36. The singers were of course conscious of the grotesqueness, of the vernacularisation, and of the fun. Some of them were reticent of singing these old songs in bad Portuguese -but all found them amusing.

37. Magita song, Samuel Mandia (Mueda: recording session, January 2005).

38. The anthem of Zuma's campaign was the struggle song umshini wami ("bring me my machine gun"). The song became extremely popular in South Africa, andembarrassingly to Zuma-was widely sung during the May 2008 "xenophobic" lynchings ( GUNNER 2009).

39. Magita song, Trovingi Rosario (Nshinga: recording session, August 2004).

40. I ground my reconstruction of Frelimo's ideology and policies on education and culture on BASTO (2006), SILIYA (1996), GOMES (1999), MAZULA (1995); on a number of Frelimo programmatic documents from 1971-1983 and on a few interviews conducted with grassroots implementers of Frelimo's cultural policies in Pemba and Muidumbe. For more detail on documents and interviews, see ISRAEL (2008: 298-299, 496).

41. "Shaping the Political Line", Mozambique Revolution, 51 (April-June 1972): 22. The title of the section is "mental scars".

42. "Message from the Central Committee to the Mozambican People", Mozambique Revolution, spec. no. (Sep 25, 1967): 5.

43. Manuel Gondola (Pemba: interview, April 2009).

44. See also Documento final do $1^{\circ}$ Seminário Cultural, reunido de 30 de Dezembro de 1971 a 21 de Janeiro de 1972, and "What is the Mozambican Culture", in Mozambique Revolution 50 (January-March 1972): 50.

45. Magita song, Fiel Liloko (Shinda: recording session, August 2008).

46. Ngoda song, Samuel Mandia (Mueda: recording session, January 2009).

47. Samuel Mandia, recording session (Mueda, July 2008).

48. Fiel Liloko, recording session (Shinda: Moçimboa da Praia, January 2008).

49. Ngoda song, Americo Nampindo (Myangalewa: recording session, August 2004).

50. Magita song, Fiel Liloko (Shinda: recording session, August 2008).

51. Limbondo song, Cinco Ramos (Mapate: recording session, July 2004).

52. Magita song, Muidumbe Jazz (Mwambula: recording session, April 2009).

53. Makwaela school choir, centro piloto of Nangade (RM archives: Maputo). 
54. On the peculiarity of the word People in Shimakonde, meaning "people from foreign settlements" (ISRAEL 2006: 122).

55. The reader can amuse herself in identifying the one post-independence piece included in this article up to this point (divided in two different paragraphs), by observing the density of such tropes. The list of tropes here is based on the analysis of around 300 political post-independence songs in Shimakonde, and comparison with an equivalent number of pre-independence songs of different genres, and from occasional listening of many more.

56. Maria-Benedita Basto speaks about a project of elimination of the "metaphorical residue" in art and literature. In a programmatic Frelimo text on poetry, Craveirinha's poem Eu sou carvão (I am coal) becomes true (in a materialistic dialectical sense) only when the figural language is converted into reality by warfare: "The words become true in a literal sense: the African has become the fire which is burning his former master. There is no metaphorical residue left between the fire of poetry and the fire of the grenades and mortars used against the enemy" (вАSTO 2006: 68-92).

57. Thus, a bewildered spectator of the II Festival of Popular Dance (Pemba 2002) asked me why in all the Makonde dances guns and bazookas featured so prominently, in a celebration whose motto was "for a culture of peace and unity".

58. Formed by the apposition of a durative verbal extension [-ang-] and a causative [-dya].

59. Far from the postcolonial celebration of the fragment, Gramsci believed that the fragmentarity of folklore was an impediment to the formation of class-consciousness, and insisted on the role of the intellectuals in coagulating "common sense" around a project of political hegemony (CIRESE 1977; GRAMSCI 1982). Thus, J.-L. AMSELLE (2008: 207-215) claims that Gramsci has been misread in postcolonial and subalternist currents.

60. Pedro Justino Seguro alerted me to this fact. The name of Bento Pachihi Nalyambipano, a relative of the more famous Teodoro Salesio Nalyambipano, also appears in a list prepared by the provincial direction of war veterans of Cabo Delgado. Bento Chipeda was another guerrilla, who was not even present at Chai.

61. Nshaila song (Mbwide: recording session, July 2004).

\section{ABSTRACTS}

Abstract

This article presents a historical reconstruction of the formation of Makonde "revolutionary singing" as genre of memorialisation of the Mozambican Liberation Struggle; tracking the "descent" of formulas and watchwords produced by the revolutionary elites into popular orality. Along this trajectory, we will encounter wartime genres that were later forgotten or foregone, which refer to moments when the "space of experience" and the "horizon of expectation" of the Struggle were still filled with uncertainty and the sense of possibility. Progressively, these singing expressions were reorganised around socialism's nodes of meaning; 
while ideological tropes, elaborated by Frelimo's "courtly" composers, were appropriated in popular singing.

Résumé

Cet article présente une reconstruction historique de la formation de la «chanson révolutionnaire " makonde, en tant que genre de mémorialisation de la lutte de Libération nationale mozambicaine, tout en enregistrant la « descente » de formules et slogans produits par les élites révolutionnaires dans l'oralité populaire. Au cours de cette trajectoire, nous allons rencontrer des genres chantés pendant la guerre, qui seront plus tard oubliés ou abandonnés, faisant référence à des moments dans lesquels les "champs d'expérience » et l'«horizon d'attente" de la lutte sont encore marqués par l'incertitude et le sens de possibilité. Progressivement, ces expressions chantées furent réorganisées autour des modes signifiants du socialisme; et les tropes idéologiques, élaborés par les compositeurs de « cour » du Frelimo furent appropriés dans la chanson populaire.

\section{INDEX}

Mots-clés: Mozambique, Frelimo, lutte de libération, chanson populaire, populisme

Keywords: Mozambique, Frelimo, Liberation Struggle, Popular Song, Populism

\section{AUTHOR}

\section{PAOLO ISRAEL}

Centre for Humanities Research, University of the Western Cape, Bellville, Afrique du Sud. 